\title{
Environment News Futures
}

\section{International Polar Foundation}

A Belgian scientific research station in Antarctica is dealing with an outbreak of Covid-19, despite workers being fully vaccinated and based in one of the world's remotest regions.

Since 14 December, at least 16 of the 25 workers at the Princess Elisabeth Polar Station have caught the virus.

Officials say cases remain mild so far.

"The situation isn't dramatic," Joseph Cheek, a project manager for the International Polar Foundation, told the BBC.

\section{A \$10bn Glittering Space Jewel Recedes into the Distance}

This is the moment the James Webb telescope came off the top of its rocket to begin its mission to image the first stars to shine in the cosmos.

The video was transmitted in near real-time last Saturday, but the feed to Earth was very glitchy and broken up.

The European Space Agency (Esa) has since had the sequence cleaned up and set to music by the UK artist Charlotte Hatherley.

It's the last view we'll ever get of the telescope scientists believe will go on to make transformative discoveries about the early Universe, and about planets circling far-off stars.

\section{Climate Change will Expand the Range of Tropical Cyclones, Making Millions More People Vulnerable to These Devastating Storms, a New Study Says}

At present, these cyclones - or hurricanes as they are also known - are mainly confined to the tropical regions north and south of the equator.

But researchers say that rising temperatures will allow these weather events to form in the midlatitudes.

This area includes cities such as New York, Beijing, Boston and Tokyo.

The study has been published in the journal Nature Geoscience. 


\section{French Ban on Plastic Packaging for Fruit and Vegetables Begins}

Published 31 December 2021

A new law banning plastic packaging on most fruit and vegetables comes into effect in France from New Year's day.

Cucumbers, lemons and oranges are among the 30 varieties banned from being wrapped in plastic. Larger packs as well as chopped or processed fruit will be exempt.

President Emmanuel Macron called the ban "a real revolution" and said it showed the country's commitment to phase out single use plastics by 2040.

More than a third of fruit and vegetable products in France are thought to be sold in plastic wrapping, and government officials believe that the ban could prevent a billion items of single use plastics being used every year.

In a statement announcing the new law, the Environment Ministry said that France uses an "outrageous amount" of single use plastics and that the new ban "aims at cutting back the use of throwaway plastic and boost its substitution by other materials or reusable and recyclable packaging".

\section{Grassroots Heroes}

\section{The Next Wave: Empowering Global Change}

At the foot of Morocco's Atlas mountains, nourished by rivers and fertile soils, lies Séfrou, a small Berber town with a deep agricultural history. Known for its production of fruit including apples, plums, oranges, cherries and olives, Séfrou is home to traditional family farmers who still grow crops in the methods taught by their forefathers.

However, in line with global warming trends, Morocco faces the prospect of rising temperatures, a decline in rainfall and an increased risk of drought and, without access to refrigeration, food is more likely to rot quickly and go to waste. Expensive cooling units are not an option for many farmers like those in Sefrou. Although some of the food is rescued for animal fodder, most of it is thrown away. And completing the vicious cycle is the fact that food waste is estimated to contribute to $8 \%$ to $10 \%$ of global greenhouse gas emissions.

Established in 2001 to help Séfrou's rural villages access education, health and clean water, JIBER has broadened its reach into a co-operative non-profit which, among other things, buys unsold waste produce from farmers and merchants, and, using specialised equipment, converts them either into other products, including cosmetic oils and face masks, or simply dried fruit for desserts or condiments. These are then sold at markets in Fez and Séfrou.An important part of JIBER's mission, says general director Donat Bukasa, is the socio-economic integration and skillsbuilding of young people in the region. "We have now taken on 12 young employees, two people full-time and the rest part-time," he says. "They meet two to three times a week in the building where the co-operative is located." (See Snapshot 1) 


\section{First Ever True Millipede with over 1,000 Feet Found in Australia}

FP | Updated: Dec 16, 2021, 21:42 IS

Read more at:

http://timesofindia.indiatimes.com/articleshow/88325062.cms?utm_source= contentofinterest\&utm_medium $=$ text\&utm_campaign $=$ cppst

PARIS: Scientists have discovered the world's first true mil ..

(See Snapshot 2)

\section{Himalayan Glaciers Melting at 'Exceptional Rate' Due to Global Warming: Study}

The researchers found that the Himalayan glaciers have lost ice ten times more quickly over the last few decades than on average since the last major glacier expansion 400-700 years ago, a period known as the Little Ice Age.

\section{Palm Oil's High Yield Masks Environmental Impact}

Advocates see higher yields per hectare as a path to sustainable palm oil, but face scepticism around land conversion and life-cycle emissions when it comes to sustainability, "palm oil is simply the superior crop for its effective land utilization," according to the Malaysian Palm Oil Council. It argues that oil palm produces far more oil on far less land than other major global oil seed crops such as sunflower, rapeseed and soybean. The Indonesian Palm Oil Association, a governmentaligned group of major producers in the world's top palm oil exporting country, says palm oil's land efficiency makes it "the perfect balance between land for conservation and land for agricultural development". 


\title{
CAPITAL PUBLISHING COMPANY
}

\section{Recent and Forthcoming Publications \\ on \\ Climate Change and Environmental Sciences}

\author{
Mohanty \\ Advanced Numerical Modeling and Data Assimilation Techniques for \\ Tropical Cyclone Predictions \\ Goel \\ Rakhecha \\ Behera \\ Nagarajan \\ Advances in Soil and Hazardous Waste Management \\ Applied Hydrometeorology \\ Subramanian \\ Bioenergy for Sustainability and Security \\ Climate and Natural Resources \\ Asthana \\ Nagarajan \\ Křeček \\ Sikdar \\ Kónya \\ Talapatra \\ Coastal Environments - Focus on Asian Regions \\ Dam Engineering \\ Drought Assessment \\ Ecosystem Services of Headwater Catchments \\ Environmental Management: Issues and Concerns in Developing Countries \\ Environmental Sustainability Education for a Changing World \\ Geochemical Exploration and Modelling of Concealed Terrestrial and Offshore \\ Mineral Deposits \\ Naqvi \\ Basavaiah \\ Raju \\ Geology and Evolution of the Indian Plate (From Hadean to Holocene - 4 GA to 4 KA) \\ Geomagnetism: Solid Earth and Upper Atmosphere Perspectives \\ Geostatistical and Geospatial Approaches for the Characterization of Natural \\ Resources in the Environment: Challenges, Processes and Strategies \\ Mitra \\ Sikdar \\ Thangarajan \\ Ghosh \\ Ghosh \\ Thangarajan \\ Ray \\ Machiwal \\ Beheim \\ Chatterjee \\ Ramanathan \\ Krecek \\ Raju \\ Raju \\ Das \\ Kayal \\ Tiwari \\ Global Environmental Changes in South Asia: A Regional Perspective \\ Groundwater Development and Management: Issues and Challenges in South Asia \\ Groundwater Flow and Mass Transport Modeling \\ Groundwater Governance \\ Groundwater Modelling and Management \\ Groundwater: Resource Evaluation, Augmentation, Contamination, Restoration, \\ Modeling and Management \\ High Impact Weather Events over the SAARC Region \\ Hydrologic Time Series: Theory and Practice \\ Integrated Watershed Management \\ Macro-Economics of Mineral and Water Resources-Important Issues \\ Management and Sustainable Development of Coastal Zone Environments \\ Management of Mountain Watersheds \\ Management of Natural Resources in a Changing Environment \\ Management of Water, Energy and Bio-Resources in the Era of Climate Change: \\ Emerging Issues and Challenges \\ Microbial Fuel Cell: A bioelectrochemical system that converts Waste to Watts \\ Microearthquake Seismology and Seismotectonics of India \\ Modern Singular Special Based Denoising and Filtering Techniques for $2 \mathrm{~d}$ and $3 \mathrm{~d}$ \\ Reflection Seismic Data \\ Mohanty Monitoring and Prediction of Tropical Cyclones in the Indian Ocean and Climate \\ Change \\ Jha \\ Natural and Anthropogenic Disasters: Vulnerability, Preparedness and Mitigation \\ Nagarajan \\ Subramanian \\ Natural and Mad-made Disasters: Assessment and Management \\ Rivers of South Asia \\ Ramanathan \\ Behari \\ Datta \\ Kurisu \\ Sengupta \\ Mohapatra \\ Safe and Sustainable Use of Arsenic Contaminated Aquifers in the Gangetic Plain: \\ A Multi-Disciplinary Approach \\ Sustainability, Green Energy and Climate Change: Revisited \\ Theory and Principles of Simulation Modelling in Soil-Plant System \\ Trends in Asian Water Environmental Science and Technology \\ Treatment and Disposal of Solid and Hazardous Wastes \\ Tropical Cyclone Activity over the North Indian Ocean
}

For more detailed information on individual titles, please log on to our website www.capital-publishing.com 